УДК 821.163.41-1.09:398

https://doi.org/10.18485/godisnjak.2021.16.2

Зоја С. Карановић*

Универзитет у Новом Саду

Филозофски факултет
Оригинални научни рад

Примљен: 30. 09. 2021.

Прихваћен: 05. 11. 2021.

\title{
ПРЕЉА НА ВИЛИНОМ БУНАРУ. ЖИВОТ ПЕСМЕ У ВРЕМЕНУ И ПРОСТОРУ
}

У раду ће бити речи о српској народној песми која је забележена од Божице Јоцић из Селачка, у мају 1997. године, кад је ауторка текста, заједно с Весном Ђукић, радила на терену у селима око Белог Тимока. Ова песма флексибилне жанровске структуре, с мотивом отроване вилине воде, може се пратити у записима на српском демографском и културном простору у континуитету од 1780. до наших дана - од Темишвара преко Славоније, до Лике и Баније, Босне, Црне Горе и југоисточне Србије, што сведочи о њеној распрострањености и, посредно, о духовном јединству српског народа предмет је првог дела рада. Песма о забрањеној и отрованој вилиној води својим контекстом извођења, актерима, вербалним конструктима, те њиховим симболичким потенцијалима, као и варијантним манифестацијама, провоцира могућност тумачења њене садржине у оквиру обреда прелаза, што је предмет анализа у другом делу рада.

Кључне речи: преља, вилин бунар, отрована вода, историја бележења песме, српски духовни простор

*zojanko@stcable.net 


\section{Живот песме у времену и простору}

Дуго се сматрало да је песма о девојци на вилиној води, коју је Вук Стефановић Караџић штампао 1841. године (бр. 228), међу „онако митологическим", њен најстарији запис који у целини гласи:

Свилу прело злато материно,

Свилу прело, бришим препредало;

Кад је злату жећца додијала,

Баци прељу под зелену јелу,

А вретено у зелену траву,

Па отиде да водице пије;

Ал' повика нешто из бунара:

„Не пиј, злато, одовуд водице;

Овд' је вила чедо окупала,

Да је мушко не би ни жалио,

Већ је женско, не било јој живо."

Показало се, међутим, да најстарије бележење песме потиче из рукописне Песмарице Јована Николића (бр. 5, л. 13б) ${ }^{1}$, из 1780. године (настало негде у околини Темишвара), чије су одоцнело штампање омогућили Живомир Младеновић и Владан Недић (Караџић 1973: бр. 657)2:

Пролетише два златна голуба,

Крили лете, умови говоре:

„Крила наша куд нас занесосте?

Нити има дрва ни камена,

Веће једно јавор дрво суво,

И под њиме Ружица девојка.

Свилу преде, ибришим препреда.

А Ружи је додијала жеђа;

Пође Ружа да с воде напије.

1 Песму су прво објавили Живомир Младеновић и Владан Недић (Караџић 1973), затим и Марија Клеут (1995: бр. 48). Песмарииа Јована Николића налази се у Архиву САНУ, у Вуковој заоставштини под бр. 8552/264, не зна се како је рукопис доспео до Краџића. Датирана је на маргиналним белешкама, на основу којих се може утврдити да је настала између 1780 . и 1783. О власнику и записивачу ништа се поуздано не зна, мада се сматра да би то могао бити „Јован Николић који је припадао ужој околини епископа темишварског”. У овој песмарици, чији је садржај описала М. Клеут, и из ње објавила народне песме, налази се укупно 19 песама, од чега је десет 10 народних (Клеут 1988: 262-263; Клеут 1995: 302 и 352-353).

2 У Првој књизи из Караџићеве заоставштине (Младеновић и Недић) публиковано је седам народних песама из ове збирке (Караџић 1973: 404-406). Владан Недић је уочио да једна од тих песама представља варијанту поменуте Вукове и то објавио у белешци Просветиног издања (в. Недић 1975: 687). 
Ал повика чобан од оваца:

'Не пи, Ружо, те водице ладне!

Ту су воду виле обградиле,

[Обградиле], ој, опоганиле

И своје су чедо окупале,

Нит крштено, нит знаменовано.'

Ал повика вила из горице:

'Мол се Богу, чобанине млади,

Чедо ми је на крилу заспало,

Ти се не би главе наносио."”

Поменута рукописна збирка представља и документовано сведочанство о начину живота српске народне лирике у времену које је предходило Вуковој појави, истовремено потврђујући да је у усменом преношењу живела давно и међу Србима око Темишвара.

Драгоцену варијанту песме о прељи на води, која сведочи њену виталност до наших дана, забележила је, са Весном Ђукић, ауторка овог рада (2. маја 1997), од Божице Јоцић, из Селачка³ ${ }^{3}$ овако:

Свилу прела Ружица девојка,

Свилу прела на златно вретено.

Предејечи Ружа ожеднела,

Па си појде воду да си тражи.

Мало појде, три кладенца најде,

Па се сложи воду да си пије.

Овчар виче од дела голема:

„Не пиј, Ружо, ту студену воду,

Ту су воду виле омрсиле,

Омрсиле, децу окупале.”

Поменути међаши, који живот песме смештају у оквире од преко двеста година, међутим, представљају мали део онога што се у бележењима може пратити у континуитету током 19. и 20. века. Тако Вукову варијантну хронолошки следе њена четири завршна стиха, за које је Иван Кукуљевић

3 Зоја Карановић и Весна Ђукић су у селима око Белог Тимока сакупљале народне песме у неколико наврата 1997. и 1998, кад је забележено преко 250 српских народних песама, које се у облику књиге припремају за штампу. Рад на терену одијао без финансијске потпоре било које државне институције или невладине организације. Значајну логистичку помоћ пружили су нам једино Веснини деда и баба, сада већ покојни, Живана и Петар Алексић, нек им је лака земља. Рад је обављан без претходне припреме везане за сондирање терена и у вези с тим помоћи локалних власти, методом случајног одабира саговорника. Грађа је снимана касетофоном, касније диктафоном, кад је било могуће. Разговори су вођени уз пуну усмену сагласност казивача, на чему им искрено захваљујемо. Грађа с терена је у власништву сакупаљача. 
Сакцински, који их је и објавио, рекао да се „певају у Босни”, алудирајући на тада живу традицију певања на овом простору (Кукуљевић Сакцински 1851: 102) ${ }^{4}$, што ће доцнија бележења и потврдити.

О богатом животу песме у времену и њеној географској разуђености сведоче затим варијанте из Славоније, најстарија Ђорђа Рајковића (Рајковић 1869: бр. 77). Следи краљичка песма певана на први дан Духова,

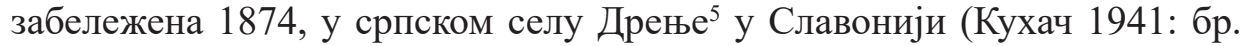
274). Запис из Подравине публиковао је, затим, Никола Беговић, у својој гласовитој збирци из Лике и Баније (1885: бр. 5), где је донео заједно са неколико ивањских песама ${ }^{6}$, овако:
Лети врана преко поља равна,
С крилма лети, с кљуном проговара:
„Десно крило, да би одагњило!
Камо си мене данас занијело?
Ђе ми нема гране ни огранка,
Само једна јаворова грана,

\begin{abstract}
${ }^{4}$ Сакцински на истом месту доноси и неколико стихова секундарно изведене варијанте, за коју каже да je: „hrvatska pjesma iz Zbelave”. Наведени одломак нема много заједничког с Вуковом и „босанском” варијантом, а с народном традицијом је повезан мотивски:

Tekla mi divojka k hladnomu studejnku,

Nagnula glavicu k hladnomu studejnku.

Na to joj nešto reče:

Nepij mi divojka te hladne vodice,

Totu su ti Vile vodu ostvarile,

$\mathrm{Ki}$ vodicu pije, crnoj zemli gnije.

(Кукуљевић Сакцински 1851: 102)

${ }^{5}$ Током истраживања ове теме ауторка рада на интернету је наишла на потресно сведочанство једне жене из овог села о нестајању Срба са ових простора „Ја сам рођена почетком 1963. године у Ђакову, када је мој деда, Срето Петровић, већ одселио за Србију. Набрђе (тј. полусрушену цркву и у коров зарасло село и гробље) сам видела једном, када је отваран спомен парк у тадашњој ЈНА касарни иако сам период пре школе и школске распусте углавном проводила неколико километара даље, у селу Дрење. Сељани су још увек препознавали где је била чија крушка, а камоли кућа. Као дете сам често од деде, оца Спасе и тетке Наде слушала и шаљиве и веома потресне приче о животу у Набрђу и увек је у тим причама било много носталгије а често и суза. Њих више нема, и готово да немам контаката са потомцима мојих стричева и тетака. Имам доста фотографија и неколико књига које су објављене, и у чијем сам стварању и ја дала скроман допринос, и понекад на Google-у укуцам неки појам или име - тако сам „набасала” и на овај Ваш текст - па се растужим над судбином тих људи, али се и обрадујем у исто време кад видим да је још некоме стало да од заборава отргне тај део историје. Нажалост, мишљења сам да смо ми последња генерација коју ова тема интересује. А и наша сећања су све блеђа а живот нам не даје довољно времена да се томе више посветимо." Светлана Петровић Гојковић https://www.poreklo.rs/2015/07/16/veliko-nabrdje/

${ }^{6}$ Укупно их је четрнаест: „Забележене у дугој Ријеци, од Милеве Париповића” (Беговић 1885: X).
\end{abstract}


Под њом сједи Ружица дјевојка,

Свилу преде, на бршљан препреда:

Изжедњела Ружица дјевојка,

Па ми иде на то поље равно,

Па ми нађе бунар воде ладне.

Приклекнула да ће се напити.

Њу ми виче вила из планина:

'Не пиј воде, Ружица, дјевојко!

Ту су воду виле осмрадиле,

И у њој су чедо окупале!'”

Хронолошки следе варијантни записи Милана Обрадовића из Западне Славоније (крај 19 века), комбиновани с другим сродним мотивима, (в. Гароња Радованац 1995: бр. 10, бр. 13, бр. 73). ${ }^{7}$ Прва песма, варирајући лик жедног јунака, у причу уводи орача. Друга, развијенија, фокусирана је на мотив девојка обећана вилама, у комбинацији с мотивом забрањене воде. Трећа песма варира мотив одбеглог јунака с девојком, којег соко на води упозорава на опасност.

Још једну песму - која у првом делу представља кратку реплику популарне теме јунак жедан иде гором и тражи воду (в. Карановић 2009б: 287-302) - записао је на почетку 20. века Павле Ровински у Црној Гори ${ }^{8}$, с одговарајућим уводним стиховима:

Гором иде лијепа ђевојка,

Гором иде, а жеђа јој преда

Тражи воде, наћи не могаше.

Капљу нађе на станцу камену,

Саже лице да с воде попије.

(према Ровински 1994: бр. 15, 483)

Варијанта Симе Милеуснића, забележена у Рогољи (западна Славонија), доспела је у Српску краљевску академију такође почетком двадесетог века (в. Гароња Радованац 1998: бр. 5). ${ }^{9}$ Запис Драгослава Алексића из Босне, из Кнежпоља (Алексић: 1933: 21) ${ }^{10}$, где је аутор бележио песме

\footnotetext{
${ }^{7}$ Срби су са свих простора данашње државе Хрватске протерани и етнички очишћени у геноцидним акцијама хрватске војске „Бљесак” и „Олуја”. Зато су овакви записи драгоцено сведочанство о вековном постојању Срба на поменутим просторима и њиховом духовном богатству.

${ }^{8}$ Песма је први пут штампана 1905.

${ }^{9}$ Милеуснић је песме слао САНУ-у, у периоду од 1900. до 1907. године (в. Гароња Радованац 1998: 7).

${ }^{10}$ Песма је публикована у одељку III, којем је приређивач дао наслов: „Сеоске пјесме, девојачке и момачке”. А самој песми, алудирајући на патријархалну социјалну матрицу, дао
} 
такође међу православним Србима ${ }^{11}$, говори о жедној чуварици говеда на забрањеној води, стиховима:

Зелени се зелена ливада,

По њој пасу шарена говеда, Чувала их Аница дјевојка.

Кад је Анђи жеђа додијала,

Оде Анђа за гору на воду.

Проговара вила из облака:

„Не пиј воде, Анице дјевојко,

Ту су воду виле саградиле

И у њојзи чедо окупале,

Да је мушко, не бих ни жалила;

Него женско, од Бога му тешко!"

Хронолошки следи варијанта Новице Шаулића, публикована тридесетих година двадесетог века (Шаулић 1936: бр. 190). Виталност песме, заједно с теренским записом из Селачка, потврђује бележење Љубише Рајковића Кожељца (1975: 90, исто 1978: бр. 61), у нашим данима, у селу Мужинац код Сокобање.

Према потврђеним изворима песма о прељи на води, дакле, певана је међу Србима, на српском демографском и културном простору, од најисточнијих до западних страна и од севера према југу, у низу самосталних варијаната од друге половине 18. века до наших дана, што документовано потврђује њен живот у временском распону од око 220 година, мада је морала бити певана и много раније.

\section{Тумачење песме}

Већ је Вук Караџић правилно антиципирао основни садржај ове кратке обредне песме (певана на први дан Духова, као краљичка и од Ивања до Петова дне ${ }^{12}$ ), кад јој је дао наслов: „Преља на вилину бунару” (бр.

\footnotetext{
је наслов „Несрећно женско”. Алексић у напомени уз песму даје податак да је публикована и код Вука под бр. 228.

${ }^{11}$ Књига Драгослава Алексића носи наслов: „Кнежпољке” и у Уводу сакупљач каже да је песме забележио од „православних”: „Од католика нисам узео ни једну из разлога што су сви досељавани тек од окупације - 1878”.

${ }^{12}$ О извођењу ове песме као краљичке (в. Кухач 1941: бр. 274). Никола Беговић забележио је песму као ивањску уз напомену: „На дугој Ријеци (у Подравини) српске дјевојке пјевају ове пјесме од Ивања, па до Петрова дне. Сваки дан под вече купе се пред црквом, па не играју, већ стојећи пјевају. Стога дадох ово име".
} 
$228)^{13}$, будући да јунакиња (преља/ преља чуварица говеда ${ }^{14}$, варијантно орач) обавља свој посао (преде, преде и чува говеда), кад изненада ожедни и на води на коју наиђе намерава да се напије, а неко је упозорава да то не чини пошто је вода отрована, виле су у њој окупале чедо... Изван ове наративне скице остали су варијантно неколики развијенији делови песме, као и њена садржинска меандрирања, о чему ће у тексту бити речи.

Песма се отвара информацијом фиктивног наратора о послу који јунакиња обавља, стиховима: „Свилу прело злато материно,/ Свилу прело, бришим препредало” (Караџић 1841: бр. 228), „Свилу прела Ружица девојка,/ Свилу прела на златно вретено” (Божица Јоцић 1997); „Свилу преде, ибришим препреда” (Караџић 1973: бр. 657)... ${ }^{15}$ Несвршени глаголски вид, неутралност, неодређеност и неограниченост трајања радње (прошле или садашње), с нагласком њене постојаности ${ }^{16}$, релативизује протицање времена које, слично бајци, обележава њену почетну ситуацију ${ }^{17}$, у којој јунакиња стрпљиво и постојано извлачи свилене нити у конац. Овај посао (који у традиционалној српској култури припада радњама припремања сватовских дарова $\left.{ }^{18}\right)$ некада је био део женских иницијација

${ }^{13}$ Иначе овај мотив у ширем митско-херојском окружењу изузетно је популаран у усменом певању Срба и јужних Словена (в. Карановић 2009б: 287-302; Вукмановић 2009: 303-332). Космогонијска борба за животворну воду једна је од најраспрострањенијих митских парадигми. За њом трагају сви прастари богови и културни хероји, од Гилгамеша, против чудовишта Хуваве; парови: Индра - Вритра; Баал - Јам; Зевс и Тифон; Аполон и Питон; Херакле, Персеј и Тезеј с разним чудовиштима; с Велосом се сукобљава Перун, а свети Ђорђе с аждајом (в. Иванов и Топров 1974: 164, 180-205), до библијских ратника, светаца и јунака епике (в. Карановић 2009б: 287-302).

${ }^{14}$ Мотивски овде припада и почетак Вукове приче о Пепељузи, где се поменуте радње комбинују и повезују: „Преле ђевојке код говеда око једне дубоке јаме, а дође некакав старац бијеле браде до појаса, па им рече: 'Ђевојке! чувајте се ви те јаме, јер да које од вас упадне вретено у њу, оне би се мати одмах претворила у краву” (Караџић 1853: бр. 32).

${ }^{15}$ Уводна формула: „Свилу прело злато материно” аналогна је такође устаљеним епским почецима (в. Детелић 1996: 54-56), што би приликом истраживања лирике требало имати на уму. Неке сличности композиционе структуре лирских песама с епском нарацијом уочио је још А. Шмаус (Schmaus 1971: 60-61).

${ }^{16} \mathrm{O}$ предењу као радњи која се доводи у везу са стварањем: в. Карановић и Пешикан 1994: 9-11; Карановић и Пешикан 1996: 5 -15.

${ }^{17}$ Бајка се отвара почетном ситуацијом (в. Проп: 1982: 34).

${ }^{18}$ Предење, плетење, ткање, вез, су типично женски, уобичајено девојачки послови, а њихове рукотворине у основи представљају свадбене дарове (в. Карановић 1992: 116-149). Рефлекси нпр. у сватовској песми:

Хај, навал мобо на крај да идемо,

На крају је зелена ливада,

У ливади јела пресађена,

И под јелом вода изведена,

И код воде убава девојка, 
и налагао управо изолованост, тајновитост и осамљивање (в. Шевалије и Гербран 1983: 431-432) из уобичајеног окружења. Сходно томе, преља се налази у својеврсној егзистенцијалној и друштвеној безвремености, сличној иницијацијком осамљивању ${ }^{19}:$ „под зеленом јелом” (Караџић 1841: бр. 228), на ливади/ на ливади за гором (Рајковић 1869: бр. 177; Гароња Радованац 1998: бр. 5; Алексић 1933: 21; Кухач 1941: бр. 274), у гори (Ровински 1994: бр. 15), који наведеним семантичким корелативима маркирају просторну границу и дивљи свет, и у контрасту су према наглашеним локусима културе (на пример херојске епике). ${ }^{20}$ Искључење из заједнице иначе је обележје ритуалне изолације и сигнализује промену у физичком и метафизичком положају иницијанта (в. Лич 1983: 77), обреди прелаза обухватају његово симболичко изопштавање (в. Мелетински 1983: $230)$, односно њима се семантизује позиција јунакиње песме. ${ }^{21}$

Ову претпоставку везану за прељу потврђују и допуњавају уводни стихови варијаната у којима се на почетку, репликом фиктивног наратора, најављују птице гласници: „Пролетише два златна голуба,/ Крили лете,

Свилу преде на златно вретенце,

Бисер ниже на орлово перце,

Кој ће јунак најпре достигнути?

Он ће узет убаву девојку.

(Станковић 1951: 27)

Формула се иначе вазује за сватовске мотиве, као: „Свилу прела, на свили седела” (Манојловић 1933: 44), који даље потврђују иницијацијску природу песме о прељи на вилину бунару.

${ }^{19}$ Које је Ван Генеп назвао обредима одвајања, односно сепарационом фазом (2005: 15-16). О издвајању у осамљивању иницијанта види и (Проп 1990: 6-75).

${ }^{20} \mathrm{У}$ епици је, за разлику од лирских песама, простор углавном географски одређен, на пример:

Књигу пише Жура Вукашине,

У бијелу Скадру на Бојани.

(Караџић 1845: бр. 25)

Вино пију два брата Јакшића,

Јакшић Дмитар и Јакшић Богдане,

У Ужицу граду бијеломе.

(Караџић 1845: бр. 97)

Вино пију три српске војводе

У богатој и поносној Мачви.

(Караџић 1862: бр. 28)

${ }^{21}$ Функција обреда одвајања је да удаље посвећеника из свакидашње егзистенције (в. Лич: 1983: 118); Ван Генеп сматра да су одвајања од претходне средине у овим ситуацијама обавезна (Ван Генеп 2005: 88-89, 105). „Венчање подразумева прелаз (...) у друштво зрелих људи, из једног клана у други, из једне породице у другу, често из једног села у друго (Ван Генеп 2005: 143). 
умови говоре”, у Песмарищи Јована Николића из 1780. (Караџић 1973: бр. 657), „Лети врана преко поља равна, С крилма лети, с кљуном проговара” (Беговић 1885: бр. 5), „Полећела два врана гаврана,/Крили лете, а перјем говоре"22, из Обрадовићеве збирке (Гароња Радованац 1995: бр. 13). Они, налик епским песмама о гавранима гласоношама, наговештавају смрт, будући да се за све три птице везује веровање о њиховој везаности за хтонски свет (в. Гура 2005: 401-402) 23 Али, у наставку се збивање концентрише искључиво на монолог птица (уместо дијалога с људским јунаком, као у епици) и отвара могућност другачијег разрешења, будући да вране, гаврани могу бити и свадбени помоћници и медијатори (в. Карановић 2011: 125-140), а да је за голуба везана и љубавно-брачна симболика (в. Гура 2005: 460), што такође допуњава иницијацијацијске потенцијале садржине песме.

Птице, затим, преузимајући улогу наратора, у иницијалном расположењу и с осећањем страха, описују простор ${ }^{24}$ у којем су се обреле, у којем такође борави преља:

Крила наша куд нас занесосте?

Нити има дрва ни камена,

Веће једно јавор дрво суво,

И под њиме Ружица девојка

(Караџић 1973: бр. 657)

Варијантно:

Десно крило, да би одагњило!

Камо с мене данас занијело?

Ђе ми нема гране ни огранка,

Само једна јаворова грана,

Под њом сједи Ружица дјевојка.

(Беговић 1885: бр. 5)

${ }^{22}$ У птицама је како се веровало, инкарнирана душа, голуб је оваплоћење добре душе, врана, зле (в. Гура 2005: 461). Али се истовремено верује да се вране на Божић претварају у голубове (в. Гура 2005: 399), односно у добре птице, што открива њихову амбивалентну симболику која је рефлектована у песми.

${ }^{23}$ Алојз Шмаус говори о композиционој схеми гаврани гласоноше који извештавају са бојишта (Шмаус 1934: 4-30; Schmaus 1971b: 228-229), ово драгоцено истраживање наговештава могућност да о неком догађају могу извештавати и друге птице, што је овде случај. Птица као јунаков помоћник иначе сигнификује прелазак у друго царство (в. Проп 1990: 256-257).

${ }^{24}$ Слично епици, али са супротним предзнаком, где гаврани гласоноше, пошто долазе из боја, најављују свој излазак из света мртвих, овде оне у њега улазе. 
Или:
„Моја крила, да би одагњила!
Куд сте мене данас занијела,
Ђено нема дрвца никаквога,
Само једно дрво ораово:
Под њима лежи јато јагањаца,
И код њих су три чобана млада,
И ш њима је Ружица дјевојка.
(Гароња Радованац 1995: бр. 13)

Просторна стварност песме даље наглашава радикалну издвојеност девојке, њено раздвајање од заједнице и профаног света, у окружењу које наликује смрти. ${ }^{25}$ Усамљени јавор и орах, као доминантни локуси у пејзажу, представљају дрвеће јаких хтонских карактеристика и места су окупљања демона (в. Чајкановић 1994: 100-101; Агапкина 2004: 559). Близину смрти и смртне опасности симболизује и квалитет дрвета-cyво, које је по прастарим веровањима место суше и жеђи, коју у дрво сабира нека зла сила, такође и вила (в. песме Карановић 2009б: 288). Јавор и орах као демонски локуси (Чајкановић 1994: 159-160; Агапкина 2004: 559), тако, већ на почетку антиципирају додир с вилом. А будући да суво дрво кодира и присуство воде коју демон скрива (в. Иванов и Топоров 1965: 85, 148; Иванов и Топоров 1974: 13, 87-88, 97-98; Толстој 1994: 57-66), то подразумева и могућност њеног ослобађања ${ }^{26}$, што је знак потенцијалног васкрсавања и новог живота којим се иницијација завршава.

Обреду прелаза одговара и начин ословљавања преље (,зллато материно”). Она, као и остали иницијанти, губи своје прелиминарно име (в. Тарнер 1986а: 41), мада и даље носи обележје припадности роду, што маркира њену амбивалентну ситуацију. Варијантно, њено име Ружица такође означава граничну позицију спремне за удај ${ }^{27}$ (в. Карановић 2009а: 19-48).

Према исказу наратора, у наставку, недостатак воде покреће радњу (слично у бајци $\left.{ }^{28}\right)$. Управо жеђ егземпларно представља проверу физич-

${ }^{25}$ Иницијанти су на неки начин мртви за овај свет, лиминалност одговара симболичкој смрти, која се у овом обреду различито испољава (в. Проп 1990: 145-161; Тарнер 1986а: 41).

${ }^{26}$ О вили која сабира изворе поред/у дрво в. Толстој 1994: 57-66. Радост Иванова, такође, сматра да се вила појављује у два вида, као олицетворење воде и растиња и као демон суше који краде воду (Иванова 1992: 29). Представа о космичком дрвету као станишту бога кише иначе је распрострањена у митовима широм света (в. Мелетински 1983: 216-217).

27 За разлику од ње, удата жена је атрибуирана везом са мужем: Гојковица, Ђурђевица, Јованбеговица и сл., док су у епици јунаци именовани и имају историјске, односно квазиисторисјке прототипове.

${ }^{28}$ Одговара функцији: јунаку нешто недостаје (Проп 1882: 43). 
ке издржљивости, што јунакињу идентификује с искушеницима који су излагани великим напорима ове врсте (в. Ван Генеп 2005: 89; Лич 1983: 118-119), овде у стиховима:

Кад је злату жећца додијала

Баци прељу под зелену јелу,

А вретено у зелену траву,

Па отиде да водице пије.

Преља, прелазећи из стања непокретности, хитро креће да тражи воду (решава се на деловање и делује ${ }^{29}$ ), при чему је тренутно убрзани проток времена - у контрасту са статичношћу почетка - остварен експресивним глаголом додијати ${ }^{30}$ и аористом глагола бацити и отићи, што такође релативизује његово протицање, као у ритуалу (в. Тарнер 1986а: 41-43). Убрзано кретање остварује се даље нагомилавањем радњи, односно истовременим лишавањем реквизита, преслица и вретено, које јунакиња „баци”, а који су женском детету давани још код рођења (в. Павлова и Толстой 1995: 342; Валенцова 2001: 102), те који симболизују њен идентитет и статус. Девојка спремна за удају користила их је радно, али су је као јаки апоторпајони и штитили (Павлова и Толстой 1994: 340-342; Валенцова 2004: 312; Валенцова 2009а: 328-330; Валенцова 2009б: 330-334). Преслица чува девојке од самовила, помаже им да не доспеју у руке демона, па су је оне увек носиле са собом (Валенцова 2001: 443-445). Бацајући преслицу јунакиња се лишава и заштите стечене код родитеља. ${ }^{31}$ И, напуштајући простор иницијалног боравка („отиде”), ступа у додир с демонским светом, којим се уводи у прелазну фазу иницијације. ${ }^{32}$ Пролаз кроз ту етапу, праћен тешкоћама, требало би да омогући укључење у нови статус, као и да отвори могућност замене старих помагала нове, од исте врсте, добија код удаје (в. Павлова и Толстой 1994: 342; Валенцова 2001: 102).

Своје алате преља спонтано баца под јелу, што је индиција локуса почетне ситуације, али и скривени наговештај додира с демонским светом, будући да је и јела локус виле прве врсте. ${ }^{33}$ Затим она, крећући се у етапама, без отежавања долази до праве препреке:

\footnotetext{
${ }^{29}$ Аналогно функцијама: јунак се одлучује на деловање и удаљава од места почетне ситуације (Проп 1982: 46).

${ }^{30}$ Припада глаголима „неконтролисаних психофизичких процеса и стања” (Стипчевић 2014: 45).

${ }^{31}$ Поред женског детета су одмах по рођењу стављали преслицу и вретено (Кабакова1999: 33).

${ }^{32}$ Ван Генеп је ову фазу обреда назвао лиминарном (Ван Генеп 2005: 15-16). О томе види и Тарнер 1986а: 40-45; Тарнер 1986б: 57-73.

${ }^{33}$ Јела је локус виле (в. Чајкановић 5 1994: 234; Агапкина 1999: 65; Карановић 2009б: 293).
} 
Па си појде воду да си тражи.

Мало појде, три кладенца најде,

Па се сложи воду да си пије.

(Божица Јоцић, Селачка 1997)

Или:

Изжедњела Ружица дјевојка, Па ми иде на то поље равно, Па ми нађе бунар воде ладне. Приклекнула да ће се напити. (Беговић 1885: бр. 5)

Она иде, љељо у гору зелену, Да потражи, љељо, бунар воде ладне.

Кад је нашла, љељо, бунар воде ладне,

Отуд виче, љељо, млади чобанине:

(Кухач 1941: бр. 274)

У паралелизмима тренутних и свршених радњи: појде - најде; иде - нађе, јунакиња доспева у туђи простор већег степена (гора ${ }^{34}$ и вилина вода ${ }^{35}$ ) где се, кршећи табу забрањеног места и сагињући се $\mathrm{e}^{36}$, као и сваки искушеник у лиминалној фази обреда, излаже опасностима (в. Мелетински 1983: 230-231) и постаје потенцијална жртва води. ${ }^{37}$ Опасност појачава место воде, као бунар који је отворени улаз у доњи свет и егземпларни локус демона (Иванов и Топоров 1965: 156; Цивјан 1982: 68; Валенцова и Виноградова 2001: 58) ${ }^{38}$, топос непријатеља прве врсте. ${ }^{39}$

У наставку, о природи опасности јунакиња сазнаје од помоћника. Супротстављени непријатељима они на њу упозоравају и, уједно, демистификују позицију иницијанта у односу на непријатеља.

${ }^{34}$ Иницијанте су иначе одводили у шуму (Проп 1990: 70, 85-104).

${ }^{35}$ О акватичкој природи виле в. Ђорђевић 1953: 81-82; Карановић 1998: 207-219; Карановић 2009б: 287-302; Вукмановић 2020; отуда топоними везани за воду садрже атрибуцију вилин (Дрндарски 1998: 98; Толстој 2001: 80-81). Вода иначе симболизује различите квалитете који се активирају у зависности од песничког контекста (Детелић 1992: 92), може бити добра и лоша.

${ }^{36}$ „Obće se pripoveda, da od one vode gde vile stanuju, čovek piti ne smie, jer ju uvek vile straže" (Sakcinski 1851: 102). Стога воду с извора не треба пити нагнут и лежећи (в. Толстој 2001: 80-81).

${ }^{37}$ О симболичној смрти искушеника у иницијацији (в. Ван Венеп 2005: 89-91).

${ }^{38}$ Силазак јунака у доњи свет (бунар) аналоган иницијацијском гутању, којем се искушеник излаже, како би добио моћи (в. Проп 1990: 343-349).

${ }^{39}$ Овај тренутак је, с тачке гледиша функција у бајци, синкретичког карактера и садржи елементе који антиципирају увођење дародавца, помоћника, али и потенцијалног непријатеља (в. Проп 1982). 
Функцију помоћника преузимају добре, горске виле:

Њу ми виче вила из планина:

„Не пиј воде, Ружица, дјевојко!

Ту су воду виле осмрадиле,

И у њој су чедо окупале!”

(Беговић 1885: бр. 5)

Варијантно, помоћник може бити неидентификовани глас из бунара:

Ал' повика нешто из бунара:

„Не пиј, злато, одовуд водице;

Овд' је вила чедо окупала",

Да је мушко не би ни жалио,

Већ је женско, не било јој живо"

(Караџић 1841:)

На опасност упозорава и чобан:

Ал повика чобан од оваца:

„Не пи', Ружо, те водице ладне!

Ту су воду виле обградиле,

[Обградиле], ој, опоганиле

И своје су чедо окупале,

Нит крштено, нит знаменовано."

(Караџић 1973: бр. 657 )

Помоћник виком, која сигнализује јачину опасности, што је сигнал промене ситуације у обреду (в. Лич 1983: 94-96), обавештава да вода није за пиће зато што су виле су њој окупале: чедо/ децу, женску, какву оне једино и рађају (в. Ђорђевић 1953: 73), варијантно дете које није крштено, ни знаменовано, чиме се интензивира припадност воде ритуално нечистом демонском свету. Варијантно, додатним акцијама, оне су воду обградиле и опоганиле (Караџић 1973: бр. 657; Рајковић Кожељац 1975: 90, исто 1978: бр. 78), отровале (Рајковић 1869: бр. 177; Кухач 1874: бр. 274; Гароња Радованац 1995: бр. 10; Гароња Радованац 1998: бр. 5), осмрадиле (Беговић 1885: бр. 5), омрсиле (Божица Јоцић 1997), замутиле (Ровински 1905: бр. 15; Шаулић 1936: бр. 190), бајале (Гароња Радованац 1995: бр. 73), што су атрибуције ритуалне нечистоће и загађености воде, и што додатно ослабљује положај ионако тренутно слабе јунакиње која се налази изван контроле своје биолошке заједнице (в. Лич: 1983:54, 118) која би јој могла бити од помоћи. 
Овим се песма и завршава, наговештавајући окончање науковања (успешно или неуспешно) и повратак преље у људски свет, али га не потврђује - крај остаје отворен. ${ }^{40}$

У одређеним варијантама иницијативу преузима чобан, као:

„Не пи воде, лијепа ђевојко,

Синој су је виле замутиле,

Некрштено чедо окупале;

Но пи винце, те румени лице"

(Шаулић 1936: бр. 190)

Он наговара девојку да одустане од пијења воде и саветује јој да се окрене овоземаљским радостима (вину које румени лице), негирајући важност онога што девојка ризикујући може добити... Овачар, сходно својим моћима, иступа и као зналац тајни и шумски маг (Плотњикова 2001: 419-421) $)^{41}$, али и преварант, будући да прекасно упозорава девојку коју је пре тога љубио, тек кад она: „Лице је умила/ Воду се напила”, остављајући јој да се сама избори с невољом које је допала:

Бре, луда девојко

Не пи туја воду,

Туј вода погана!

Туј одјутрос вила,

Лице умивала,

Чедо окупала.

(Рајковић Кожељац 1975: 90, исто 1978: бр. 78)

Мудрост овчара смењују девојачки увиди, која у завршници друге песме, на упозорење да не пије воду коју су „виле замутиле” - одговара:

„Ајд отолен од горе чобане!

Синој су је виле замутиле,

А јутрос је пером разбистриле.

Ајд отолен од горе чобане

Пасаше ти бјеле овце." -

„Нек пасају, поклали ји вуци!"

(Ровински 1905: бр. 15)

${ }^{40}$ За разлику од епских песама с овом темом, односно њихових садржинских аналогона, где се прича завршава тако што јунак ослободи воду и утажи жеђ (в. Карановић 2009б: 287-302).

41 „Считается причастным к тайнам общения с животным и растительным миром, посредником между людьми и 'тем светом'. Пастух выполняет целый ряд обрядовых действий, обеспечивающих благополучие стада” (Плотникова 2004: 637). 
И сазнањем да је вода избистрена ${ }^{42}$ и добра показује да је обучавање завршено, сходно свим правилима иницијације. У простору настањеном чудовиштима, јунакиња песме демонстрира да је овладала тајним знањима која су сваком ко се нађе у таквом окружењу неопходна (в. Мелетински 1983: 230-231).

Варијантно, мотив преље на води амалгамиран је с темом женско дете мајка клетвом предаје вилама у песми у којој она, упркос миту који јој овчари нуде, односи девојку, кад се она сагне: „да с воде напије” што je, по свему судећи, шифра неоствареног познања:

Њој долази вила на коњицу,

Узима је за бијелу руку,

Па је баца за се на коњица.

(Гароња Радованац 1995: бр. 13)

У наставку, одводећи је, вила каже: „Нисам ћела у Ружу дирати/ Док јој није удаје дорасла", чиме је рекапитулирана иницијацијска и жртвена суштина песме. ${ }^{43}$

\section{Уместо закључка}

Песма о прељи на вилином бунару спада у групу заплета који у детаљима укључују одређене елементе обреда прелаза везаних за иницијацију, односно процес прелаза у статус одраслог члана заједнице. На њену обредност, поред анализиране садржине (чија семантичка матрица је слојевита), упућују маргиналије уз два текста песме које потврђују да су је изводиле девојке о Духовима и/ или од Ивања до Петрова дне. Односно певана је у празнично време, на јавном месту, уз одређене извођачке акције, чиме су девојке истицале своју доспелост за удају (ритуално показивање). Зато наратив и није неопходно развијати, што је нужно епици, чије извођење је условљено слушањем, не акцијом.

Песма у целини говори о девојци и типично женском послу којим се спрема за удају) и, сходно томе, испевана је у лирском тону и начину, у којем доминира оријентација ка сажимању и наговештају, а след збивања

${ }^{42}$ Мућење воде као космогонијски чин у вези је с прастаром митемом о великој Богињи Мајци, која је заштитница дрвета живота и чуварица воде (коју мути) (в. Енума Елиш 1994: 53-54 и 89) и у својеврсним трансфомацијама рефлектује се у српској народној поезији, али излази из теме овог рада. О томе види: Самарџија 2007: 141-152; Трубарац 2019, са припадајућом литературом.

${ }^{43}$ Мотив отмице је такође део науковања у процесу иницијације и рефлекс онога што се дешава у бајци (в. Проп 1990: 135-139). 
само наговештава наративни поступак, тако што се догађаји именују, али не описују, већ стадијално маркирају.... Отуда је радња песме спрегнута, за разлику од акције у епској песми, која се одуговлачи и развија низом говорних секвенци, а тек онда активира. ${ }^{44}$ И у томе се огледа њена обредност.

Сходно обредној матрици, песма о прељи на вилином бунару спада у групу заплета који се граде по начелу задавање задатака и његовог испуњења, односно одговара одређеним иницјацијским радањама и, працијално, збивањима у бајци. У њој се преља, као и сваки иницијант, излаже опасностима (хоће да пије воду), непријатељи настоје да јој науде (виле трују воду), а помоћници јунакињи скрећу пажњу на опасности (горска вила, чобан). Крајњи исход, при томе, остаје непознат, као у сваком обреду, док он траје, па је и крај приче отворен (не зна се да ли је девојка пила, или није, да ли се отровала или није, нити се зна шта је после тога било). У сваком случају могућа акција повезана је с прастарим мотивом пијења забрањене воде смрти - пили су Гилгамеш и Персефона, нуђена је Одисеју у свету сенки (в. Проп 1990: 109-111), као и другим јунацима који су тамо крочили. Отуда се у различитим варијантним приступима и својеврним „интерпретацијама” певача и нуде различите могућности, мада се ни њима прича заиста не затвара. Преведено на ниво индивидулано психолошког, сусрет с вилином водом за јунакињу је прилика да учи, да разуме да свака вода није за пиће, већ да се упркос жеђи треба савладати

44 На пример:

А зло сјели, два Јакшића млада!

«У зло сјели и вино попили!

Када ваши двори изгореше,

Стара мајка коњма прегажена,

Одведени коњи из арова,

Однешено благо из ризница,

Одведена сестрица Јелица.»

Кад то чуше два Јакшића млада,

А скочише на ноге лагане,

Машише се коњма на рамена,

Отидоше право Бијограду,

А када се напојише винца,

Те им винце изиђе у лице,

А ракија приче говорити,

Поче им се Чупић туговати: „Ах, мој брате, Јанко и Вујица, тешко су ми Турци додијали,

(следи акција)

(Караџић 1862: бр. 28) 
(мада је учење обавеза сваког иницијанта и по дефиницији надилази индивидуално). Самодисциплина, самоконтрола и процес самоизграђивања, управо представљају елементе садржине због којих је песма надживела време своје обредне намене.

\section{ИЗВОРИ И ЛИТЕРАТУРА}

Агапкина 1999: Т.А. Агапкина, Дерево. Славянские древности. Этнолингвистический словарь в пяти томах: т. 2, ур. Н. И. Толстого, Москва: Институт славноведения РАН: 60-67.

Агапкина 2004: Т.А. Агапкина, Орех. Славянские древности. Этнолингвистический словарь в пяти томах: т. 3. ур., Н. И. Толстого, Москва: Институт славноведения РАН: 559.

Алексић 1933: Д. Алексић, Кнежпољке, песме из народа. Бос. Дубица.

Беговић 1885: Н. Беговић, Српске народне пјесме из Лике и Баније. Загреб: Штампарија Ф. Фишера и др

Валенцова, 2001а: М. М. Валенцова, Вретено, у Словенска митологија. Енциклопедијски речник. Ред. С. М. Толстој, Љ. Раденковић, Београд: ZepterBookWorld 102-103.

Валенцова 2001б: М. М. Валенцова, Преслица. у Словенска митологија. Енциклопедијски речник. Редактори С. М. Толстој, Љ. Раденковић, Београд: ZepterBookWorld.

Валенцова 2004: М. М. Валенцова, Мужеской-женский. Славянские древности. Этнолингвистический словарь в пяти томах: т. 3. ур., Н. И. Толстого, Москва: Институт славноведения РАН: 312.

Валенцова 2009а: М. М. Валенцова, Пряжа, Славянские древности. Этнолингвистический словарь в пяти томах: т. 4. ур., Н. И. Толстого, Москва: Институт славноведения РАН: 328-330.

Валенцова 2009б: М. М. Валенцова, Прялка, Славянские древности. Этнолингвистический словарь в пяти томах, т. 4. ур., Н. И. Толстого, Москва: Институт славноведения РАН: 330-334.

Валенцова и Виноградова 2001: М. М. Валенцова и Л. Н. Виноградова, Бунар, Словенска митологија. Енциклопедијски речник. Ред. С. М. Толстој, Љ. Раденковић, Београд: ZepterBookWorld.

Ван Генеп 2005: А. Ван Генеп, Обреди прелаза, прев. Ј. Лома, Београд: СКЗ.

Вукмановић 2009: А. Вукмановић, Водена вила и вилина вода, у Moћ къижевности, ур. М. Детелић, Београд, Балканолошки институт САНУ. 
Вукмановић 2020: А. Вукмановић, У трагању за извир водом. Нови Сад: Академска књига.

Гароња Радованац 1995: С. Гароња Радованац, Сриске народне пјесме из Западне Славоније, у записима М. Обрадовића, прир. С. Гароња Радованац, Топуско, Книн; Београд; Нови Сад: Српско културно друштво „Сава Мркаљ”, Информативна агенција Искра.

Гароња Радованац 1998: С. Гароња Радованац, Српске народне пјесме из околине Пакраца и Пожеге у записима Симе Д. Милеуснића. Загреб: Просвјета.

Гура 2005: А. Гура, Симболика животиња у словенској народној траищији, прев. Љ. Јоксимовић и др., Београд: Logos.

Детелић 1992: М. Детелић, Митски простор и епика. Београд: САНУ, Ауторска издавачка задруга „Досије”.

Детелић 1996: М. Детелић, Урок и невеста, поетика епске формуле, Београд:Балканолошки институт САНУ.

Дрндарски 1998: М. Дрндарски, Вила бродарица и вила изворкиња - сличности и разлике, Расковник, јесен/зима: 96-105.

Ђорђевић 1953: Т. Ђорђевић, Вештииа и вила у нашем народном веровағу и предању. Београд: САНУ.

Енума Елиш, 1994: Енума Елиш сумерско-акадски мит о стварању, прев. М. Вишић. Нови Сад: Источник.

Иванов и Топоров 1965: В. Иванов и В. Топоров, Славянские языковые моделиру ющие системы, Москва: „Наука”.

Иванов и Топоров 1974: В. Иванов и В. Топоров Исследования в области славянских древностей: Лексические и фразеологические вопросы реконструкиии текстов. Москва: „Наука”

Иванова 1992: Р. Иванова Епос, обред, мит, София: БАН.

Кабакова 1999: Г. И. Кабакова, Девочка Славянские древности. Этнолингвистический словарь в пяти томах: т. 2, ур. Н. И. Толстого, Москва: Институт славноведения РАН: 33-34.

Карановић 1992: З. Карановић Свадба и дар, или дијалог који траје, у зб. „Поетика дара и даривања у југословенским књижевностима”, ур. М. Радовић, Домети, пролеће-лето, Сомбор: 116-149.

Карановић 1998: 3. Карановић, Неки аспекти просторног ситуирања виле у усменој традицији балканских Словена, Кюижевна историја, 30, 1998, 105, 207-219.

Карановић 2009а: 3. Карановић, Ружа у српској традиционалној култрури и народној поезији, Синхронијско и дијахронијско изучавање врста у српској књижевности, ур. 3. Карановић и И. Живанчевић-Секеруш Нови Сад, Филозофски факултет: 19-48. 
Карановић 2009б: 3. Карановић, Митске реминисценције о јунацима српске епике и вили бродарици (јунак и демонско биће у борби за животворну воду), Моћ књижевности, ур. М. Детелић, Београд, Балканолошки институт САНУ: 287-302.

Карановић 2011: 3. Карановић, Гавран и соко као свадбени медијатори у три сватовске песме (или заборављена прича о иницијацији)". Птище: књижевност, култура. Уредници М. Детелић, Д. Бошковић. Крагујевац: Центар за научна истраживања САНУ и Универзитета: 125-140.

Карановић и Пешикан Љуштановић 1994: 3. Карановић и Љ. Пешикан Љуштановић Послави и дани српске песничке традиције. Нови Сад: Светови.

Карановић и Пешикан Љуштановић 1996: 3. Карановић и Љ. Пешикан Љуштановић, Трагови представа о митско-религијским аспектима предења и ткања у српској усменој традицији, Кюижевна историја: 5-15.

Караџић 1841: В. Ст. Караџић Српске народне пјесме, скупио и на свијет издао Вук Стеф. Караџић, књига прва. Беч: Штампарија јерменскога манастира.

Караџић 1845: В. Ст. Караџић, Српске народне пјесме, скупио и на свијет издао Вук Стеф. Караџић, књига друга. Беч: Штампарија јерменскога манастира.

Караџић 1853: В. Ст. Караџић, Српске народне приповијетке, скупио и на свијет издао Вук Стеф. Караџић. Беч: Штампарија јерменскога манастира.

Караџић 1862: В. Ст. Караџић, Српске народне пјесме, скупио и на свијет издао Вук Стеф. Караџић, књига четврта. Беч: Штампарија јерменскога манастира.

Караџић 1973: В. Ст. Караџић, Српске народне пјесме из необјављених рукописа Вука Стеф.Караиића, књига прва, Различне женске пјесме, за штампу приредили Живомир Младеновић и Владан Недић, САНУ, Београд, 1973.

Клеут 1988: М. Клеут, Српске рукописне песмарице као извори за проучавање усменог песништва, Т. Бекић и др. Српско грађанско песништво, Нови Сад: Матица српска.

Клеут 1995: М. Клеут, Српске рукописне песмарице као извори за проучавање усменог песништва, Народне песме у српским рукописним песмарииама XVIII и XIX века, Нови Сад, Београд: Матица српска, Институт за књижевност и уметност, 259-265.

Кукуљевић Сакцински 1851: I. Kukuljević Sakcinski, Vile, Arkiv za povjesnicu jugoslavensku I, Zagreb: Družtvo za jugoslavensku povestnicu. 
Kухач 1941: F. Kuhač, Južno-slovjenske narodne popievke vol. 5, ur. B. Šuroja i V. Dukat. Zagreb: JAZU.

Лич 1983: E. Lič, Kultura i komunikacija, prev. B. Hlebec, Beograd: Prosveta.

Манојловић 1933: К. П. Манојловић, Свадбени обичаји у Пећи, ГЕМ VIII, 44: 39-51.

Мелетински 1983: Е. M. Meletinski Poetika mita, prev. J. Janićijević, Beograd: Nolit.

Недић 1975: В. Недић Српске народне пјесме, књ. прва, Сабрана дела Вука Караџића, 1975. прир. Владан Недић, Београд: Просвета.

Павлова и Толстой 1994: М. Р. Павлова, и Н. И. Толстой, Веретено Славянские древности. Этнолингвистический словарь в пяти томах, т. 1. ур. Н. И. Толстого, Москва: Институт славноведения РАН: 340-342

Плотњикова А. А 2001: Пастир, Словенска митологија. Енциклопедијски речник. Редактори С. М. Толстој, Љ. Раденковић, Београд: ZepterBookWorld: 419 - 421.

Плотникова А. А 2004: Пастух Славянские древности. Этнолингвистический словарь в пяти томах: т. 3. ур., Н. И. Толстого, Москва: Институт славноведения РАН: 637 - 641.

Проп 1982: V. Ja. Prop, Morfologija bajke. prev. P. Vujičić idr. Beograd: Prosveta.

Проп 1990: V. Ja. Prop, Historijski korjeni bajke, prev. V. Flaker, Sarajevo, 1990.

Рајковић 1869: Ђ. Рајковић Српске народне песме (женске), већином из Славоније, Нови Сад: Матица Српска.

Рајковић Кожељац 1975: Љ. Рајковић Кожељац, Народне песме из сокобањског краја. Развитак бр. 4-5: 87-93.

Рајковић Кожељац 1978: Љ. Рајковић Кожељац, Здраваи миришљаваи, народне песме и бајалице из тимочке крајине.

Ровински 1994: П. А. Ровински Црна Гора у прошлости и садашњости,тIII, Цетиње - Сремски Карловци: Издавачки центар - Централна народна библиотека Ђорђе Црнојевић - Издавачка књижарница Зорана Стојановића.

Самарџија 2007: С. Самарџија, Обредна стварност и метафора у једној песми из Ерлангенског рукописа, Зборник реферата и саопштењ а са Међународног научног састанка слависта у Вукове дане, 36/2. Београд: Међународни славистички центар: 141-152.

Станковић 1951: Ж. Станковић, Народне песме у Крајини. Београд: Музиколошки институт САНУ. 
Стипчевић 2014: Б. Стипчевић, Дативне рекиијске конструкције с непрелазним глаголима у савременом српском језику, докторска дисертација https://nardus.mpn.gov.rs/bitstream/handle/123456789/4078/Disertacija.pdf

Тарнер 1986а: В.Тарнер, Варијације на тему лиминалности. Градина 10, 40-56.

Тарнер 1986б: Т. Тарнер, Трансформација, хијерархија и трансценденција: једна преформулација Ван Генеповог модела структуре обреда прелаза. Градина 10, 57- 73.

Толстој 1994: Н. И. Толстој, Митолошко у словенској народној поезији: међу два бора (јела), прев. Љ. Раденковић, Расковник, пролеће, лето: 57-66.

Толстој 2001: С. М. Толстој Вила, Словенска митологија. Енциклопедијски речник. Ред. С. М. Толстој, Љ. Раденковић, Београд: Zepter Book World 80-82.

Трубарац 2019: Ђ. Трубарац, У јеленовом колу: мотив јелена у сриској обредној лирици Београд: Етнографски институт САНУ.

Чајкановић 1994а: В. Чајкановић, Речник српских народних веровања о биљкама. Сабрана дела, књ. IV, прир. В. Ђурић, Београд: СКЗ, БИГЗ, Просвета.

Чајкановић 1994б: В. Чајкановић Стара српска религија и митологија. Сабрана дела, књ. V, прир. В. Ђурић, Београд: СКЗ, БИГЗ, Просвета.

Цивјан 1982: Т. В. Цивјан, Семантика просторних и временских показатеља, прев. Р. Мечанин), Расковник IX/31, Београд: 68-71.

Шаулић 1936: Н. Шаулић, Српске народне песме, књ. I, св. 4, Београд.

Шевалије и Гербран 1983: J. Scevalier i A. Gheerbarant Rječnik simbola, Zagreb: Nakladni zavod Matice hrvatske.

Шмаус 1934: А. Шмаус, Гавран гласоноша, Прилози проучавању народне поезије, св. 1, Београд: 4-30.

Шмаус 1971a: A. Šmaus, Vrsta i stil u narodnom pesništvu, Usmena književnost, prir. M. Bošković-Stulli, Zagreb, 1971, 59-63.

Шмаус 1971b: A. Schmaus, Iz studija o krajinskoj epici// Usmena književnost, prir. M. Bošković-Stulli, Zagreb, Školska knjiga: 219-248. 
Zoja S. Karanović

\title{
FOLK SONG ABOUT A THIRSTY GIRL ON FORBIDDEN FAIRY WATER - HISTORY OF RECORDING AND INTERPRETATION
}

\begin{abstract}
Summary
The subject of this paper is a Serbian ritual folk song that Zoja Karanović and Vesna Đukić recorded in in the village Selačka (Southeastern Serbia) in 1997. The main thopic of this song is related to a thirsty spinster girl on the water which was poisoned by a fairy who bathed her child in it. In the past, the song was a part of ritual practice and was performed by gearls on Pentecost and around Midsummer day. The song used to be popular everywhere among Serbs. And it can be traced in records from 1780 to the present days. This song about forbidden and poisoned fairy water with its context of performance, figurs, verbal constructs, and their symbolic potentials, as well as variant manifestations, provokes the possibility of interpreting its content within the rite of passage, which is the subject of analysis.
\end{abstract}

Key words: ritual song, history of recording, thirsty spinster girl, faires well, poisoned water, Serbian cultural space 